\title{
Optimalisasi Manajemen Kenyaman Wisata di Rumah Makan Saung Sobat, Garut
}

\author{
Suryana \\ STP ARS Internasional \\ suryana.suy@bsi.ac.id
}

\begin{abstract}
ABSTRAK
Optimalisasi Manajemen Kenyamanan Wisata di rumah makan Saung Sobat merupakan hasil penelitian bidang manajemen pariwisata dalam paparan kualitatif deskriptif. Manajemen Kenyamanan Wisata adalah salahsatu hal yang utama dalam pelayanan pariwisata. Rumah makan Saung Sobat berusaha melakukan optimalisasi manajemen kenyamanan wisata dalam pelayannannya yang sudah berjalan selama beberapa tahun. Hal ini dibuktikan dengan penyajian pelayanan dengan optimalisasi manajemen kenyamanan wisata bahkan keamanan bagi para pengunjung yang direalisasikan dalam berbagai hal seperti letak restauran yang strategis, tata letak area parkir, ruang makan indoor dan outdoor yang berupa saung-saung yang terletak diatas kolam dan dekat dengan area parkir yang membuat para tamu merasakan kenyamanan dan juga disajikan sisi lain yaitu live music sebagi hiburan dan penambah kenyamanan berada didalam rumah makan beserta keramahan khas daerah Prahyangan. Itulah wujud dari implementasi optimalisasi manajemen kenyamanan wisata dalam pelayanan sebuah restauran, Rumah Makan Saung Sobat, Garut.
\end{abstract}

Kata Kunci : Optimalisasi, Kenyamanan Wisata, Kualitas Pelayanan

\begin{abstract}
The Optimal Tourism Comfortability Management at Rumah Makan Saung Sobat is the result of a tourism management research in qualitative-descrptive method. The management of tourism comfortability is a prime point in tourism service. Rumah makan Saung Sobat tries to optimize the management of tourism comfortability in it services having been operated in years. It is proved in serviec operation by optimizing mangement of tourism comforability plus safety service for the customers realizing in variuos such as the strategic restaurant location, parking area position, indoor dinningroom and outdoor denoting samll bamboo houses located on ponds near parking area that can make the customers feel comfortable and the other side is live music as amusement adding comfortability being in the restaurant with the regional cordiality of Parahyangan. It is the realization of the tourism comfortability management optimizing in the service of a Restaurant, Rumah Makan Saung Sobat.
\end{abstract}

Keywords : Optimizing, Tourism Comfortability, Service Quality

Naskah Masuk : 5 Januari 2018

Naskah Direvisi: 8 Januari 2018

Naskah Diterima : 6 April 2018

ISSN: 2355-6587, e-ISSN: 2528-2220

http://ejournal.bsi.ac.id/ejurnal/index.php/jp 
PENDAHULUAN

Dalam penelitian terdahulu tentang kualitas pelayanan di restaurant dilakukan oleh Subakti (2014). Dia (subakti) mengaskan: "Restaurant ......... adalah bagian dari akomodasi pariwisata yang berperan memenuhi kebutuhan wisatawan atau customer". Begitu penting peran sebuah restaurant dalam dunia pariwisata dengan berbagi pelayanannya yang sangat dibutuhkan. Berdasarkan pernyataan peneliti diatas, maka manjaemen pelayanan dalam pariwisata adalah hal yang harus mendapat perhatian besar dari pihak produsen, mengingat persaingan dalam pelayanan pariwisata kini semakin ketat dengan berbagai program yang dimiliki oleh pihak-pihak penjual.

Kebutuhan untuk berwisata pada saat ini yang membutuhkan fasilitas-fasilitas pelayanan tertentu memang tidak bisa dihindari. Wisata sebagai hiburan manakala kepenatan menyerang anggota masyarakat tertentu, karena berbagai kelompok masyarakat dipacu dengan berbagai kebutuhan yang harus dipenuhi dan ditambah dengan beban keinginan yang mungkin bisa lebih besar. Kondisi ini mengakibatkan tekanan dalam anggota masyarakat tersebut. Untuk melepaskan rasa lelah dari tekanan, maka masyarakat sangat mebutuhkan hiburan. Salah satu objek hiburan adalah rumah makan, dimana pelanggan bisa mencari makanan favorit sambil menikmati udara segar dan hiburan lainnya. Hal ini merupakan gaya hidup dari konsumen, dan gaya hidup bisa disalurkan atau didapat di rumah makan tetentu. Walker (2011) memberikan alasan; "Restaurants play a significant role in our lifestyles" (Restauran memainkan peran yang sangat berarti dalam gaya hidup kita).

Yuniarti (2015 ) mengemukakan: "Budaya dan perilaku konsumtif bagian dari gaya hidup". Rupanya hal inilah yang nampak sangat mempengaruhi pada perkembangan bisnis sebuah rumah makan, sehingga harus menjadi pusat perhatian, karena banyak orang datang ke sebuah rumah makan tidak hanya untuk menikmati makanan atau minuman yang tersedia, namun juga mencari atmosfir lain yang bisa memenuhi kebutuhan yang menghibur, seperti sajian live music. Musik di rumah makan bukanlah sesuatu yang baru, namun umumnya rumah makan menyajikan musik hanya sebagai penghidup suasana makan, dan ini biasanya diputar dari sebuah audio player yang disalurkan pada pengeras suara dengan posisi tertentu diberbagai ruangan dengan tingkat volume yang dianggap nyaman pada sisi pendengaran konsumen.

Untuk memenuhi apa yang dibutuhkan oleh konsumen, sebuah rumah makan disarankan untuk memperhatikan environmental psychology atau psikologi lingkungan (Katsigris dan Thomas, 2009) yang menurut dua penulis itu akan membantu dalam operasional pelayanan dalam menyajikan ketertarikan dan kenyamanan bagi para tamu.

Selanjutnya Katsigris dan Thomas (2009) menjelaskan:

"This is the study of the deep, even primal reasons that people feel certain ways about seating, lighting, music, and other design elements". (Ini adalah suatu kajian dari alasaan-alasan utama bahkan mendalam bahwa masyarakat membutuhkan caracara tertentu mengenai tempat duduk, pencahayaan, musik dan elemen-elemen rancangan lainnya.).

Inilah salah satu realita dalam menjalankan menajemen pelayanan yang merupakan tantangan berarti bagi daya tahan dan kemajuan sebuah rumah makan yang dalam implementasinya dilapangan harus mengacu pada selera, gaya, dan cara makan dalam permintaan konsumen. Environmental psychology ini tentunya bisa dihidupkan dengan live music salahsatunya.

Seperti yang diungkap diatas bahwa persaingan bisnis kini semakin ketat, sehingga berbagai cara dilakukan baik yang berbau tradisional maupun modern untuk meningkatkan kualitas pelayanan dalam rangka memuaskan pelanggan agar tetap menjadi pelanggan yang potensial bahkan potensialitasnya diusahakan terus meningkat tidak hanya dalam jangka pendek, tapi juga dalam jangka panjang 
seperti yang dinginkan oleh organisasi perusahaan. Dalam atmosfir seperti dibutuhkan pelayanan yang di-manage secara profesional di berbagai bidang bisnis seperti yang diungkap Tjiptono (2012):

"Layanan prima telah menjadi tuntutan yang wajib dipenuhi setiap organisasi bisnis agar mampu bersaing secara efektif dalam pasar yang kian kompettitif dewasa ini,"

Untuk menyajikan layanan prima maka dibutuhkan dukungan yang harus implementasikan dari empat orientasi pasar, yaitu : product, production, sale dan marketing (Boddy, 2014). Dengan dukungan empat poin ini, maka layanan prima diharapkan bisa berjalan sebagaimana mestinya, dan demikian juga dengan efek jangka panjangnya. Sebuah organisasi bisnis diharapkan akan mampu bertahan dan bertahan dengan mempertahankan dan meningkatkan pelayanan prima tadi. Namun mengaplikasikan pelayanan prima ini tidaklah mudah bagi program pelayanan organisasi bisnis, karena masalah pelayanan ini adalah masalah yang menyangkut berbagai hal sehingga "We must look into the total service lifecycle, " (Kita harus melihat dan mempertimbangkan siklus kehidupan dalam pelayanan mutlak) (Qiu, 2014). Itulah salahsatu aspek pelayanan yang harus diperhatikan dan tentunya ada dilapangan seperti yang diungkap diatas, dan membutuhkan manajemen strategi yang harus dijalankan oleh perusahaan dalam menjalankan pelayanan, dengan manajemen strategi ini, maka program pelayanan diharapkan akan berjalan sebagaimana mestinya.

Karena manajemen strategi merupakan salahsatu bagian utama dalam mengaplikasikan layanan prima tadi, maka dengan manajemen strategi ini layanan prima bisa disiasati dengan berbagai cara atau strategi. Dengan strategi-strategi yang ada dan sudah dimiliki oleh sebuah organisasi bisnis, maka organisasi bisnis tersebut diharapkan akan mampu menjalankan layanan prima, sehingga organisasi bisnis yang memiliki layanan prima dan sudah berjalan segabaimana mestinya seperti yang diharapkan oleh organisasi dalam persaingan bisnis, berarti organisasi bisnis tersebut telah menemukan manajemen strategi yang tepat yang menggerakan layanan prima tadi. Hal ini bisa berhubungan dengan istilah yang disebut strategy formulation (Stevenson, 2015). Dalam strategy formulation, Stevenson (2015) mengemukakan tiga strategi primer; leading capacity strategy, following strategy, tracking strategy. Lalu Dia (Stevenson) menjelaskan;

"A leading capacity strategy membangun kapasitas dalam mengantisipasi peningkatan permintaan di masa yang akan datang................ A following strategy membangun kapasitas ketika permintaan melebihi kapasitas yang ada. A tracking strategy sama dengan a following strategy, namun strategy ini menambah kapasitas dalam tambahan gaji yang relatif kecil untuk menjaga langkah dalam menghadapi peningkatan permintaan".

Apa yang dijabarkan oleh Stevenson diatas merupakan bentuk kedisiplinan manajemen dalam menjalankan manajemen pelayanan untuk menciptakan layanan prima. Bagi organisasi bisnis yang sedang berusaha memberikan layanan prima, strategi-strategi diatas adalah bagian yang tidak dapat dipisahkan dengan program layanan prima yang sedang dijalankan, dan tentunya hal ini bukanlah hal yang mudah bagi organisasi bisnis baru ketika menggunakan strategi-strategi diatas, karena layanan prima adalah layanan yang dinamis yang tentunya harus selalu mengadakan perubahan sesuai dengan situasi pasar yang menjadi kenginan dan kebutuhan para pelanggan yang sangat menginginkan kepuasan dari penyedia layanan atau organisasi bisnis, terutama "Produk-produk intangible diyakini lebih sulit dievaluasi, karenanya bisa menimbulkan tingkat ketidakpastian dan persepsi risiko yang besar" (Tjiptono, 2012). Ini pernyataan yang susah dibantah, 
karena apa yang dikemukakan ini merupakan hal yang bisa berakibat fatal jika tidak diperhatikan dan harus diakui pula bahwa hal ini merupakan hal yang tidak mudah untuk diaplikasikan karena menyangkut tingkat ketidakpastian yang nampak ditekankan dalam pernyataan diatas.

Berdasarkan pemaparan latar belakang diatas mengenai manajemen untuk mempertahankan dan mengembangkan bisnis rumah makan, maka sangatlah dibutuhkan optimalisasi manajemen, baik itu optimalisasi dalam manajemen sumberdaya pariwisata maupun optimalisasi dalam manajemen pelayanan.

Menurut KBI (2008), kata optimalisasi adalah kata yang berasal dari kata optimal yang diartikan terbaik; paling menguntungkan. Akar kata optimalisasi dalam bahasa Inggris adalah optimize yang berarti "to make something as good as possible" (Cambridge Advance Learner's Dictionary). Kata ini digunakan oleh Lamb, et al dalam mendefinisikan Customer Relationship Management (CRM). Menurut Lamb, et al., (2013):

"Customer Relationship Management is a company-wide strategy designed to optimize profitability, revenue, and customers satisfaction by focusing on precisely defined customer groups." (CRM adalah strategi besar sebuah perusahaan yang dirancang untuk mengoptimalkan prifitabilitas, penghasilan, dan kepuasan pelanggan dengan fokus pada kelompokkelompok pelanggan yang jelas)."

Dengan teori yang dijabarkan oleh Lamb et al. (2013) diatas yaitu tentang optimalisasi dalam manajemen, dan juga teori-teori dari pakar lainnya yang menjadi acuan tentang nilai optimal yang akan dibahas, maka penelitian ini fokus pada optimalisasi yang menjadi judul dan sub judul dalam kajian literatur untuk pengembangan teoritis dalam manajemen sumberdaya pariwisata, manajemen pelayanan dan manajemen memahami perilaku konsumen sambil mensinyalir dan menelusuri realita dilapangan pada objek-objek penelitian tentang optimalisasi manajemen kenyamanan wisata.

\section{KAJIAN LITERATUR \\ Optimalisasi Manajemen sumberdaya Pariwisata pada Out-door Restaurant.}

"Dalam konteks pariwisata, sumberdaya diartikan sebagai segala sesuatu yang mempunyai potensi untuk dikembangkan guna mendukung pariwisata, ...." (Pitana dan Diarta, 2009). Pernyataan dua penulis diatas menunjukan bahwa sumberdaya pariwisata sangat melimpah. Sumberdaya pariwisata di negara kita memiliki berbgai jenis yang bisa ditumbuh-kembangkan untuk memajukan daerah dimana sumberdaya pariwisata itu ada, dan tentunya diharapkan akan memberi dampak positif pada masyarakat sekitar dalam perkembangan ekonomi positif yang berujung pada kesejahteraan bersama.

Selanjutnya Pitana \& Diarta (2009) menjelaskan tentang 4 bentuk sumberdaya pariwisata: "..... sumberdaya alam, sumberdaya budaya, sumberdaya pariwisata minat khusus, disamping sumberdaya manusia”. Untuk sumberdaya pariwisata minat khusus ini terdiri dari 10 klasifikasi: active adventure, nature and wild life, affinity, romance, family, soft adventure, history/culture, hobby, spiritual, sports. (Richardson dan Flucker dalam Pitana dan Diarta, 2009).

Semua sumberdaya pariwisata yang ada tentunya harus didukung dan diprogram dengan sumberdaya manusia yang tepat guna untuk mengoptimalisasi sumberdaya yang dianggap potensial baik jangka pendek maupun jangka panjang dengan berbagai syarat yang dibutuhkan demi lancarnya program-program yang ada.

Kutipan-kutipan dari para pakar tersebut diatas menunjukan bahwa rumah makan adalah sumberdaya pariwisata yang potensial yang didalamnya ada sumberdaya pariwisata budaya, karena rumah makan itu sendiri adalah salahsatu produk budaya yang menyajikan makanan dalam berbagai menu yang juga produk dari budaya yang merupakan bentuk nilainilai yang ada dan berlaku di lingkungan sekitar, karena "Culture is the set of 
values...." (Daft, 2010). Rumah makan beserta produk-produknya yang disediakan tentunya merupakan nilai-nilai budaya yang sangat diharapkan menjadi komoditi potensial bagi perkembangan sebuah organisasi bisnis terutama dalam hal ini bisnis pariwisata. (Pitana dan Diarta, 2009).

Dalam sebuah outdoor restaurant sumberdaya budaya dan sumberdaya alam yang diungkap oleh Pitana dan Diarta, tentuya sangat besar, karena didalamnya ada makanan yang merupakan produk budaya seperti yang diungkap diatas, tempat makan yang khas yang ditempatkan diruang terbuka juga merupakan produk budaya yang didukung dengan keberadaan "suhu dan kelembaban udara yang nyaman" (Demanik dan Weber dalam Pitana dan Diarta, 2009), dimana fasilitas yang disediakan alam ini sangat membantu manajemen untuk memuaskan pelanggan. Demikian juga dengan "sumberdaya pariwisata minat khusus" yang diungkap Richardson dan Flucker dalam Pitana dan Diarta (2009) juga bisa diciptakan dengan memfasilitasi ruangan atau tempat seperti tempat bermain musik atau bernyanyi yang dilengkapi dengan berbagai audio equipment, instrumen musik dan personil yang dibutuhkan seperti musisi yang bisa membimbing pelanggan bermain musik atau menyanyi dan juga penyanyi selalu siap menghibur pelanggan untuk bernyanyi bersama.

Untuk memlengkapi teori yang dibutuhkan, disini perlu dikemukakan juga bahwa sajian musik ini merupakan sumberdaya budaya pada poin 3 (seni pertujukan) dari tujuh poin yang diungkap oleh Pitana dan Diarta (2009). Seni pertujukan dalam budaya berbentuk musik salahsatunya adalah pentas musik dengan menggunakan organ tunggal yang siap menyajikan berbagai jenis musik yang dibutuhkan pelanggan dengan kepiawaian seorang musisi didalam sebuah rumah makant yang merupakan sebuah "Usaha sarana pariwisata" (Wardiyanta, 2006).

Dalam dunia bisnis pariwisata, tentunya segala sesuatu harus dibuat semenarik mungkin, hingga sesuatu itu menjadi layak untuk dinikmati sebagai kesenangan yang berujung kepuasan pelanggan. Itulah produk dari suatu potensi pariwisata yang sangat diharapkan oleh konsumen (Boniface, 2003). Dengan demikian, Produk atau potensi pariwisata yang ada dalam penggunaannya harus terus ditingkatkan hingga mencapai tingkatan optimal.

Untuk mencapai tingkatan optimal tentunya ada proses optimalisasi. Untuk mencapai yang terbaik dengan menjalankan proses optimalisasi ini tentunya dibutuhkan manajemen yang tepat untuk mengolah sumberdaya pariwisata yang ada, karena menurut Weis (2014): “..... business must be organized to provide optimal value creation .........." (...... bisnis harus diorganisir untuk memberikan kreasi nilai yang optimal...........). Demikian penjelasan seorang pakar tentang optimalisasi dalam manajemen yang tentunya sangat esensial, dimana optimalisasi manajemen sumberdaya pariwisata di era globalisasi sangat membutuhkan kecepatan dan kecermatan dalam implementasi dan pengoperasian.

Optimalisasi Manajemen Pelayanan dalam Restauran Sebagai Daya Tarik

Dalam dunia bisinis, dikenal dengan apa yang disebut etika. Weis (2014) menjelaskan bahwa kata etika berasal dari bahasa Yunani ethos yang bermakna karakter.

"Ethics involves understanding the difference between right and wrong thinking and actions, ......." (Etika melibatkan pemahaman tentang perbedaan-perbedaan antara yang benar dan yang salah berfikir dan bertindak). (Weis, 2014)

Dalam dunia pelayanan etika sangatlah dibutuhkan, karena dalam pelayanan pihak yang melayani harus memahami keinginan para pelanggan, dengan membedakan antara yang salah dan yang benar tadi dalam atmosfir tertentu, maka proses pelayanan diharapakan akan berjalan sebagaimana mestinya dan bisa diterima oleh pihak yang membutuhkan pelayanan tadi. Dengan memperhatikan masalah 
etika, maka pelayanan didalam sebuah restauran harus disesuaikan dengan produk yang ditawarkan. Dengan penyesuaian seperti ini, maka etika dalam bisnis diharapkan akan berjalan sebagaimana mestinya. Selanjutnya dijelaskan:

“..... approaching problems using a moral frame of reference can influence solution paths as well as options and outcomes." (..... masalah-masalah pendekatan yang menggunakan kerangka moral dari suatu acuan bisa mempengaruhi jalur-jalur solusi yang sama baiknya dengan pilihanpilihan dan dampaknya). (Weis, 2014)

Disini solusi untuk mencapai optimalisasi manajemen pelayanan juga harus dipertimbangkan dengan kerangka moral yang berlaku, kerangka moral ini biasanya mengedepankan sopan-santun dalam melayani. Dengan sopan-santun dalam melayani, maka diharapkan pelanggan akan merasa dihargai sebagaimana mestinya dan sewajarnya sebagai pihak pembeli yang kemudian diharapkan akan kembali tertarik untuk melakukan transaksi baik dalam jangka pendek maupun panjang terutama. Ini merupakan wujud dari manajemen mempertahankan pelanggan dengan optimalisasi manajemen pelayanan demi kepuasan.

Hal tersebut merupakan Service Operations Strategy (Hollins dan Shinkins, 2006) yang merupakan realisasi dari optimalisasi manajemen pelayanan, karena tujuan jangka panjang dari pelayanan adalah "to create value for customers to earn their lifetime loyalty" (Tesco dalam Hollins dan Shinkins, 2006). Manajemen pelayanan dioperasikan dengan program jangka pendek dan jangka panjang yang tentunya dalam tuntutan service climate (Dana Yagil dalam Schneider dan Barbera, 2014) yang menekankan pada "what we focus on around here" (Schneider, Macey \& Young dalam Dana Yagil dalam Schneider \& Barbera, 2014).

Salahsatu bentuk "what we focus on around here" adalah me-manage apa yang disebut unoccupied time atau waktu yang tidak diisi (Maister dalam Tjiptono 2012), dimana ketika pelanggan menunggu pesanan atau pelayanan yang bisa membuat pelanggan mersa tidak nyaman berada di lokasi tertentu dengan waktu luang yang ada, hal ini harus menjadi perhatian pihak manajemen penyedia layanan. Sehingga apa yang diungkap para pakar diatas tentang optimalisasi manajemen demi tercapainya pelayanan yang membuat para pelanggan mendapatkan kepuasan dalam memenuhi keinginan dan kebutuhannya, diharapkan akan melahirkan kesan baik yang merupakan kepuasan menjadi pelanggan dengan mutu pelayanan tertentu.

Optimalisasi manajemen pelayanan akan lebih baik lagi jika didukung dengan apa yang disebut "Additional Dimesnsions of Service Quality" atau Dimensi Tambahan Mutu Pelayanan (Boddy, 2014), yang terdiri dari tiga poin; Responsiveness (Pemberian reaksi), Assurance (Kepastian, jaminan), Empathy (Empati). Lalu Boddy (2014) menjelaskan tiga kata tersebut: "Responsiveness - rasa sudi yang kuat untuk membantu pelanggan dan menyediakan pelayanan yang cepat", tentunya hal ini sangat dituntut para pelanggan pada umumnya. Lalu, "Assurance - kemampuan bersikap dan berperilaku yang menginspirasi keyakinan." Ini adalah masalah melayani sambil menyajikan keyakinan yang menumbuhkan kepercayaan dari pihak pelanggan. Selanjutnya poin yang ketiga adalah "Empathy - memahami dan memperlihatkan perhatian pada pelanggan". Hal ini adalah sikap yang bisa menyentuh sisi emosi positif pelanggan untuk tetap menjadi pelanggan. Semua itu adalah efektifitas komunikasi pelayanan yang terkesan wajar dengan pelanggan atau pelayanan sebagaimana mestinya dengan batas-batas tertentu yang bisa meningkatkan kepercayaan akan pelayanan yang diterima oleh pelanggan.

Tiga poin yang diungkap diatas, oleh Boddy (2014) disebut intangible features yang merupakan langkah-langkah untuk menciptakan kesan positif pada para pelanggan yang memang membutuhkan pelayanan seperti yang diharapkan, yang selanjutnya bisa memberikan kepuasan dan kenyaman bahkan keamanan wisata, 
karena pelanggan sangat mempercayai kualitas pelayanan yang diberikan oleh pihak manajemen yang bersangkutan. In service operations intangible features affect perceptions of quality (Boddy (2014).

Itulah sebagian dari usaha dalam rangka optimalisasi manajemen pelayanan dari teori-teori yang sangat logis dan handal untuk diimplementasikan dilapangan, karena optimalisasi pelayanan yang dimanage oleh pihak terkait memang harus mengacu pada tuntutan pasar atau konsumen. Dengan cara seperti ini, maka proses optimalisasi dalam pelayanan bisa dimaksimalkan lewat potensi atau fasilitas yang tersedia yang memang layak dijadikan komponen dalam proses pelayanan yang akan menjadi daya tarik bagi para pelannggan dan calon pelanggan.

Optimalisasi Manajemen Memahami Perilaku Konsumen Produk Pariwisata

Sebagai produsen yang selalu dituntut menjadi profesional tentunya harus memahami perilaku konsumen. Konsumen memperlihatkan perilaku tertentu, tentunya memiliki motivasi. Kajian motivasi dari konsumen ini haruslah masuk pada item utama manajemen pelayanan atau manajemen garapan lainnya dalam ranah penyediaan produk atau jasa. Ada ungkapan Nilai pelanggan dan kepuasannya (Kottler, et al., 2013). Para pakar tersebut membahas hal ini dalam nada peringatan tentang pengharapan pelanggan yang harus menjadi perhatian yang besar, karena:

"If they set expectation too low, they may satisfy those who buy but fail to attract enough buyers. If they set expectation too high, buyer will be disappointed" (Jika mereka men-set pengharapan terlalu rendah, maka mereka mungkin memuaskan pihak pembeli namun gagal menjaring pembeli dalam jumlah seperti yang diharapkan. Jika mereka men-set pengharapan terlalu tinggi, maka pihak pembeli akan kecewa). (Kottler, et al., 2013)

Begitulah peringatan yang terlontar, dimana pengharapan yang disajikan harus sesuai dengan porsi yang diinginkan pihak pembeli. Jika pihak penjual sudah mampu merealisasikan pengharapan yang disajikan, disitu tentunya diharapkan akan muncul kepercayaan dari para pembeli yang bisa dikembangkan menjadi pelanggan yang setia pada produk tertentu, karena: Kepuasan pelanggan dan nilainya merupakan blok bangunan atau benteng kunci untuk mengembangkan dan memanage hubungan dengan pelanggan. (Kottler, et al., 2013). Apa yang diungkap oleh para pakar tersebut adalah merupakan langkah-langkah dalam mengoptimalisasi manajemen tentang pelanggan yang selanjutnya bisa digunakan untuk mempertahankan dan menarik calon pelanggan menjadi pelanggan setia. Itulah nilai pelanggan yang harus dipelihara dengan memahami perilaku-perilakunya. Nilai-nilai ini adalah sesuatu yang tidak dapat dipisahkan dalam program optimalisasi manajemen bagi sebuah organisasi atau restaurant, karena cara-cara yang disaranakan para pakar diatas merupakan wujud dari kepahaman organisasi atau restauran tentang kebutuhan dan keinginan para pelanggannya. Untuk mengetahui keinginan dan kebutuhan pelanggan tentunya ada hubungan yang baik antara penjual dengan pembeli, dan hubungan itu harus dibangun yang tentunya membutuhkan waktu.

Para pakar lain juga memberikan peringatan dalam masalah perilaku konsumen yang bermuatan utama kebutuhan dan keinginan, "The behavior of consumers is often irrational and unpredictable" (Perilaku konsumen itu sering tidak rasional dan susah diprediksi) (Ferrell dan Hartline, 2014). Namun pihak penjual atau produsen tetap harus memenuhi apa yang diminta konsumen agar perusahaannya berjalan dengan baik. Disinilah manajemen berperan yang bisa diopersikan secara spesifik, dalam hal ini adalah manajemen memahami perilkau konsumen untuk mengimbangi atmosfir tertentu antara pihak manajemen dan konsumnen atau proses optimalisasi manajemen. 
Tentunya hal ini bukan hal yang sederhana untuk dijalankan, karena

"mempengaruhi konsumen untuk membeli suatu produk bukanlah hal yang mudah, apalagi mendapatkan kepercayaannya sehingga konsumen menjadi loyal dengan suatu produk.," (Yuniarti, 2015).

Dengan fakta seperti ini, maka pihak penjual atau produsen harus memiliki manajemen untuk mengantisipasi hal ini, diantaranya:

“...... Perusahaan harus memahami dan dapat mempelajari keinginan konsumen, memprediksi hal-hal yang ada dalam pikiran konsumen ......." (Yuniarti, 2015).

Demi lancarnya proses optimalisasi manajemen dalam rangka memahami perilaku konsumen, selanjutnya kita harus dalami motif dan motivasi konsumen. Hal seperti ini ada dalam faktor individual yang sangat susah dipahami dan juga susah berubah menurut Ferrel dan Hartline (2014):

"Faktor-faktor individual lainnya, seperti persepsi, motif, minat, opini, atau gaya hidup adalah hal-hal yang jauh lebih susah dipahami, karena faktor-faktor tersebut tidaklah serupa atau bersamaan dengan karakteristik demografik seperti usia, gender, atau level pendapatan."

Dari pernyataan diatas tergambar betapa sulitnya memahami arah perilaku konsumen, hal ini menuntut profesionalitas yang tinggi bagi pihak penjual untuk memahaminya dengan cara terus menjalankan program survey bagi para konsumen, sehingga operasional manajemen bisa seimbang dengan situasi yang berkembang pada pihak konsumen.

Selanjutnya, menjalankan manajemen memahami konsumen, rupanya harus pula menggunakan Strategic customers Management (Piercy \& Lane (2009). Dua pakar tersebut menyarakan integrasi. Menurut KBI (2008), Integrasi berarti penyatuan hingga menjadi kesatuan utuh atau bulat. Langkah yang disarankan adalah; "Getting your act together around customer value". (Piercy \& Lane, 2009). Itulah yang ditekankan dalam integrasi dengan menyiapkan berbagai perangkat yang menjadi bagian yang tidak bisa dipisahkan. Dalam pernyataan dua pakar diatas (Piercy \& Lane), berarti bahwa dalam melayani pelanggan kita harus memperhatikan atau me-mange berbgai proses tentang nilai dimana berbagai proses tersebut harus didukung dengan perangkat lainnya. Demikian makna dari pernyataan dua pakar tersebut diatas.

Manajemen memahami perilaku konsumen dalam produk pariwisata diusahakan mengarah pada hal-hal yang menjadi kesenangan dan kegembiraan para pelangan, karena berwisata merupakan aktifitas mencari kesenangan untuk menghindari hal-hal yang sifatnya menekan secara psikologis, para konsumen perlu saat-saat melepaskan ketegangan tersebut dengan menikmati fasilitas atau produk yang disajikan para penjual dan produsen yang selalu dituntut memahami keingin para pelanggan. Untuk mencapai hal tersebut dibutuhkan penelitian yang cukup lama dalam segmen pasar tertentu agar arah program manajemen memahami pelanggan secara jelas dan tepat mengenai sasaran pada segmen tertentu.

\section{METODE PENELITIAN}

Penelitian ini menjelaskan tentang bagaimana proses komoditi dilingkungan pariwisata atau produk pariwisata disajikan untuk dikonsumsi seperti yang dikemukakan oleh Wardiyanata (2006) berdasarkan manajemen terkait.

Untuk menggali informasi dari lokasi penelitian, penulis mengadakan "Tahapan penjajakan (Grand Tour)" dan "Menggali fokus penelitian (Mini Tour)" (Putra, 2013) dengan mengunjungi objek penelitian, dan teknik pengumpulan data yang digunakan adalah interview dalam hal ini penulis menggunakan unstructured interview (interviu tak berstruktur) yang diungkap Esterberg dalam sugiyono (2016).

Selanjutnya penulis melengkapi data yang perlu untuk melengkapi data-data penelitian dengan komunikasi jarak jauh yang disebut oleh Brassington dan Pettitt (2013) sebagai Personal interviews yang 
bisa dilakukan di berbagai tempat tertentu. Masih menggunakan saran dari dua penulis diatas (Brassington dan Pettitt), selanjutnya penulis merumuskan dan menjabarkan permasalahan yang ada, lalu disimpulkan dengan meyoroti berbagai hal yang layak dan terbuka untuk interpretasi sehingga penelitian ini masuk pada kategori penelitian kualitatif deskriptif.

\section{PEMBAHASAN}

\section{Sekilas tentang Rumah Makan Saung} Sobat.

Rumah Makan Saung Sobat berlokasi di Jalan Raya Garut-Tasikmalaya KM.3. Daerah ini terletak di dipingiran kota Kabuputen Garut, Jawa Barat. Dengan suasana desa, hawa pegunungan dan terletak di daerah pesawahan dalam atmosfir pertanian Parahiyangan yang menjadi daya tarik.

Rumah makan yang dibangun pada tahun 2013 ini menyajikan menu utama; ayam bakar madu, ikan bakar madu, udang bakar madu, plus berbagai olahan sayur dan minuman ringan.

Lahan parkir yang luas dan nyaman berlokasi didalam area restaurant yang bisa membuat tamu merasa aman dengan kendaraan yang di parkir di atas area parkir yang terbilang nyaman karena berdekatan dengan saung-saung tempat makan. Ini adalah fasilitas manajemen kemanan dan kenyamanan rumah makan dalam hal kendaraan milik tamu.

Disamping itu ada juga saung-saung yang menghadap area parkir sehingga para tamu tetap bisa melihat langsung kendaraan yang terparkir. Sebenarnya dari semua saung yang ada, pengunjung bisa melihat kendaraan yang terpakir sambil menikmati sajian menu dan live music. Sedangkan ruang makan indoor terletak didekat gerbang masuk.

Konsep outdoor restaurant sebagai konsep utama dari Rumah Makan ini dengan tempat makan yang berupa saung-saung. Saung-saung ini merupakan Bangunanbangunan yang terkesan teduh dalam suasan santai, dan terbuat dari bambu dengan gaya makan lesehan plus fasilitas ritual (mushola, dan tempat wudhu).
Diantara saung-saung yang ada dengan gaya lesehan, terdapat satu saung berada di pinggir kolam dengan ukuran yang lebih besar dan berlokasi sangat berdekat dengan pesawahan warga yang menjadi latar pemandangan alam yang asri. Saung ini berbentuk persegi panjang. Disini bukan konsep lesehan tapi disediakan kursi dan meja makan terbuat dari bambu dengan posisi bergaya didalam rumah yang terletak didepan panggung yang ada di ujung Saung.

Didepan kursi-kursi dan meja gaya rumahan ini terdapat ruang bagi tamu untuk menyanyi bahkan menari. Di atas panggung kecil ini ada satu organ dan seorang music player yang siap menghibur tamu dengan posisi menghadap meja-meja dan kursi-kursi tamu.

\section{Hal-hal yang Essensial dalam Pelayanan di Rumah Makan Saung Sobat}

Dalam proses pelayanannya, ada hal-hal yang esensial yang terpantau oleh penulis, yaitu; Tamu dipersilahkan menikmati musik atau menyanyi sebelum dan sesudah makan dengan ditemani seorang musisi yang siap melayani. Para pengunjung dipersilahkan berdansa ria di area depan panggung yang representatif dalam suasana alam terbuka. Kebanyakan tamu menikmati musik setelah menyantap menu utama.

Pelayanan ini merupakan hal yang esensial karena bisa menciptakan kenyamanan yang memang diprogram oleh manajemen rumah makan Saung Sobat yang menyajikan pelayanan dalam keramahan khas budaya daerah di Tatar alam Parahyangan. Hal ini di-set agar para pelanggan merasa berada dalam suasana kekeluargaan dengan suasan lingkungan psikologis perkampungan khas Parahiyangan yang bisa terkesan berada di perkampungan sanak saudara dalam acara kunjungan keluarga.

Dari uraian diatas, berarti manjemen Rumah makan ini mengoptimalkan berbagai sumberdaya pariwisata demi kenyamanan para tamu.

Strategi Pelayanan di Rumah Makan Saung Sobat

Berdasarkan penjabaran dalam pembahasan teori-teori diatas dan juga 
pengamatan penulis dilapangan, semua itu merupakan manajemen kenyamanan wisata Rumah makan Saung Sobat bagi para pengunjung dengan optimaliassi berbagai potensi yang ada yang dirancang demi kenyamana yang terbilang cukup baik dan di-set dalam suasana seramah mungkin.

Rumah makan Saung Sobat mempertimbangkan hal-hal tersebut dengan langkah-langkah optimalisasi sbb:

1. Menyediakan ruang musik untuk pengunjung yang ingin bermain musik dengan fasilitas sound system. Untuk pengunjung yang ingin menyanyi, pihak manajemen restaurant menyediakan organ player professional yang selalu standby. Menyanyi atau bermain musik biasa dilakukan oleh pengunjung sambil menunggu hidangan yang sedang diproses, sehingga selama ada di lokasi terasa menyenangkan bagi para tamu yang memang ingin menikmati waktu dengan kesenangan sebaik mungkin seperti yang ditawarkan manajemen Rumah Makan Saung Sobat.

2. Membebaskan pengunjung berada di restauran selama jam buka. Hal ini dimaksudkan supaya pengunjung merasakan suasana tempat yang terkesan tempat sendiri atau keluarga ketika mereka berada di area Rumah Makan Saung Sobat dan merasakan atmofir wisata kunjungan pada keluarga yang sebenarnya.

3. Meng-update berbagai fasilitas seperti memodifikasi saung tempat makan dengan mengubah bagian-bagian tertentu dari saung sehingga tetap terlihat memiliki tampilan yang menarik dan sedikit berbeda karena modifikasi-modifikasi tersebut.

4. Meningkatkan pelayanan dengan menambah fasilitas di saung yang menjadi ruang musik, seperti meningkatkan kualitas sound system diatas panggung.

5. Menciptakan suasana kekeluargaan antara pihak manajemen rumah makan dengan para tamu atau pengunjung dengan cara bercengkrama antara pengelola atau pemilik dan juga para pramusaji dengan para tamu sehingga terjadi hubungan emosional positif (kekeluargaan) antara kedua belah pihak.

6. Meningkatkan penggunaan dan penempatan atau pemakaian bahasa pada tamu dengan kata atau bahasa yang memberi kesan jauh lebih positif. Artinya dengan kata, ungkapan atau bahasa tertentu bisa membuat para tamu merasa sangat nyaman dan merasa sangat dihargai. Disini para pramusaji menggunakan bahasa daerah (Sunda) jika tamu mengajaknya berbahasa Sunda, dan untuk tamu yang tidak berbahasa Sunda, maka dilayani dengan bahasa Indonesia. Hal ini bisa menjadi penelitian berikutnya tentang penggunaan kata, ungkapan dan kalimat bagi para pramusaji dalam melayani tamu di rumah makan di Saung Sobat.

\section{PENUTUP}

Dari paparan diatas baik itu merupakan teori maupun yang ada di lapangan, penulis menyimpulkan bahwa optimalisasi manajemen kenyamanan wisata dalam peningkatan mutu pelayanan yang dijalankan di Rumah Makan Saung Sobat merupakan strategi yang cukup tepat karena strategi yang digunakan adalah strategi optimalisasi dalam pelayanan dengan keramahan pada para pengunjung yang diarahkan untuk merasakan berada diperkampungan sanak saudara yang sedang dikunjungi dan tentunya dalam suasana keakraban dan kekeluarga dengan latar tradisi budaya Sunda Tatar Parahyangan daerah Garut yang menyajikan kenyamanan dalam bercengkrama.

Strategi yang dijalankan rumah makan Saung Sobat masih bisa dikembngkan dan sangat potensial untuk berkembang mengingat lokasi yang cukup strategis, yaitu berada di lokasi yang dilewati transportasi antara daerah Garut dan Tasikmalaya. Dengan mempertimbangkan lokasi yang strategis ini pihak manajemen Rumah Makan Saung Sobat bisa menambah fasilitas dan produk atau pelayanan lain sebagai inovasi dalam 
optimalisasi manajemen kenyamana wisata.

Adapun saran-saran yang

direkomendasikan adalah sebagai berikut:

1. Agar disediakan website yang terus ter-update yang mudah diakses oleh para pelanggan atau calon pelanggan untuk mendapatkan berbagai informasi tentang Rumah Makan Saung Sobat.

2. Sebaiknya disediakan lebih dari satu organ player agar proses pelayanan dalam komunikasi antara music player dengan pengunjung lebih lancar untuk men-transfer kemampuan-kemampuan bermusik dan menyanyi dengan cara yang menghibur (hal ini perlu penelitian yang lebih mendalam)

3. Agar disediakan penyanyi yang selalu standby (laki-laki dan perempuan) yan mampu melantunkan berbagai jenis lagu dan juga mampu mengajak para pengunjung untuk nyanyi bersama.

4. Meningkatkan sikap yang bisa lebih mengikat hubungan emosional dengan pelanggan sehingga menjadi pelanggan yang lebih potensial dalam waktu jangka panjang. Hal ini tentunya disesuaikan dengan etika yang berlaku, sehingga kesan positif akan tetap terjaga yang selanjutnya bisa mengarah dan berkembang pada wilayah pemahaman yang lebih positif tentang selera pelanggan.

5. Agar disediakan menu lain atau makanan khas dari daerah lain. Hal ini untuk memancing pengunjung dari daerah-daerah lain yang banyak berkunjung ke Kota Garut. Bisa pula untuk memancing para tamu lokal yang ingin mencicipi menu lain selain menu yang menjadi khas di Rumah makan Saung Sobat. Ketersediaan makanan lokal dan daerah lain ini merupakan sesuatu yang unik untuk diteliti, mengingat pada umumnya restaurant menyajikan menu khas dari salahsatu daerah atau negara tertentu sebagai menu utama.

6. Meningkatkan kemampuan bahasa Asing dan pengembangan diri bagi para pramusaji agar kemampuan berkomunikasi terus meningkat dalam melayani para pelanggan pada jangkauan yang lebih luas.

\section{REFERENSI}

Brassington, Frances., Pettitt, Stephen. (2013). Essentials of Marketing. THIRD EDITION. Harlow, England. London. New York. Boston. San Francisco. Toronto. Sydney. Auckland. Singapore. Hongkong. Tokyo. Seoul. Taipei. New Delhi. Cape Town. São Paulo. Mexico City. Madrid. Amsterdam. Munich. Paris Milan: PEARSON

Boddy, David. (2014). Management: An Introduction. Sixth Edition. Harlow, England. London. New York. Boston. San Francisco. Toronto. Sydney. Auckland. Singapore. Hong Kong. Tokyo. Seoul. Taipei. New Delhi. Cape Town. São Paulo. Mexico City. Madrid. Amsterdam. Munich. Paris. Milan: Pearson

Boniface, Priscilla. (2003). Managing Quality Cultural Tourism. Rouledge: London and New York. Taylor \& Francis e-Library: USA and Canada.

Cambridge Advance Learner's Dictionary. (2008). 3rd Editon. Version 3.0.

Daft, Richard. L. (2010). Organization Theory and Design. Tenth Edition. SOUTH-WESTERN CENGAGE Learning: Australia. Brazil. Japan. Korea. Mexico. Singapore. Spain. United Kingdom. United States.

Ferrel \& Hartline. (2014). Marketing Strategy: Texts and Cases. Sixth Edition. Australia. Brazil. Japan. Korea. Mexico. Singapore. Spain. United Kingdom. United States: SOUTH-WESTERN CENGAGE Learning

Hollins \& Shinkins. (2006). Managing Service Operations: Design and 
Implementation. London. Thousands Oaks. New Delhi: Sage Publications.

Katsigris, Costas., Thomas, Christ. Third Edition. (2009). Design and Equipment for Restaurants and Food Service: A Management View. Hoboken, New Jersey. Canada: John Wiley \& Sons, INC.

Lamb, Charles W., Hair, Jr, Joseph F., McDaniel, Carl. (2013). Marketing. Twelfth Edition. Australia. Brazil. Japan. Korea. Mexico. Singapore. Spain. United Kingdom. United States :SOUTH-WESTERN CENGAGE Learning.

Pitana, I Gede., Diarta, I Ketut Surya. (2009). Pengantar Ilmu Pariwisata. Penerbit Andi:

Piercy, Nigel F \& Lane, Nikala. (2009). Strategic Customer Management: Strtegizing the Sales Organization. Oxford. New York. Auckland. Cape Town. Dar es Salaam. Hong Kong. Karachi. Kuala Lumpur. Madrid. Melbourne. Mexico City. Nairobi. New Delhi. Shanghai. Tapei. Toronto: Oxford University Press.

Putra, Nusa. (2013). Metode Penelitian Kualitatif Manajemen. Jakarta: Divisi PBuku Perguruan Tinggi PT RajaGrafindo Persada.

Qiu, Robin G. (2014). Service Science: The Foundation of Service Engineering and Management. Hoboken, New Jersey. Canada: John Wiley \& Sons, Inc.

Schneider, Benjamin., Barbera, Karen M., Ed. (2014). The Oxford Handbook of Organizational Climate and Culture. Oxford. New York. Auckland. Cape Town. Dar es Salaam. Hong Kong. Karachi. Kuala Lumpur. Madrid. Melbourne. Mexico City. Nairobi. New Delhi.
Sanghai, Taipei. Toronto: Oxford University Press.

Sugiyono. (2016). Metode Penelitian Manajmen: Pendekatan: 1. Kuantitatif 2. Kualitatif 3. Kombinasi (Mixed Methods) 4. Penelitian Tindakan (Acion Research) 5. Penelitian Evaluasi. Bandung: Alfabeta.

Stevenson, William J. (2015). Operations Mangement. Twelfth Edition. New York: McGraw-Hill Education.

Subakti, Agung Gita. (2014). Analisa Kualitas Pelayanan di Restauran Saung Mirah, Bogor. http://journal.binus.ac.id/index.php/ BBR/article/view/1195/1063 diaccess tanggal 3 September 2017

Tjiptono, Fandi. (2012). Service Management. Edisi 2. Yogyakarta: Penerbit Andi.

Walker, John R. (2011). Restaurant: from Concept to Operation. Hoboken, New Jersey. Canada: John Wiley \& Sons, Inc.

Wardiyanta. (2006). Metode Penelitian Pariwisata. Yogyakarta: Penerbit Andi.

Yuniarti, Vina Sri (2015). Perilaku Konsumen: Teori dan Praktik. Bandung: Penerbit PUSTAKA SETIA.

\section{BIODATA PENULIS}

Suryana, Staf Pengajar Sekolah Tinggi Pariwisata ARS Internasional, Bandung untuk bidang Manajemen dan Bahasa yang sangat tertarik dengan bidang Pariwisata. S1diselesaikan di Fakultas sastra Unfari Bandung. S2 di Program Pasca Sarjana Magister Manajemen (Manajemen Sumberdaya manusia) di Universitas Bina Sarana Informatika, Bandung. 